Rev. Bras. Saúde Prod. Anim., Salvador, v.16, n.3, p.544-557 jul./set.., 2015 http://www.rbspa.ufba.br

\title{
Digestibility of phosphorus in powder and microgranular phosphate in diets for pigs
}

\author{
Digestibilidade do fósforo em fosfato em pó e microgranular em dietas para suínos
}

\author{
ROCHA JUNIOR, Carlos Magno da ${ }^{1 *}$; TEIXEIRA, Alexandre de Oliveira $\dagger$; HANNAS, \\ Melissa Izabel $\uparrow+$; SANTANA, Ana Lúcia Almeida ${ }^{1}$; CARVALHO, Thony Assis ${ }^{1}$; \\ OLIVEIRA, Bárbara Lopes de ${ }^{1}$; MOREIRA, Leonardo Marmo†; BRIGHENTI, Carla \\ Regina Guimarães† $\dagger$
}

\author{
${ }^{1}$ Universidade Federal de Viçosa, Departamento de Zootecnia, Viçosa, Minas Gerais, Brasil. \\ †Universidade Federal de São João Del Rei, Departamento de Zootecnia, São João Del Rei, Minas \\ Gerais, Brasil. \\ †U Universidade Federal de Viçosa, Departamento de Zootecnia, Viçosa, Minas Gerais, Brasil. \\ *Endereço para correspondência: carlosmagno.rocha@yahoo.com.br
}

\section{SUMMARY}

This study was realized with the objective to determine the apparent and standardized digestibilities of phosphates to pigs in growing phase, employing two methodologies. Forty-two crossbred barrows with an initial weight of $37 \pm$ $1.1 \mathrm{~kg}$ were used in a randomized-block design in a $2 \times 7$ factorial arrangement, with two collection methods: total fecal collection and the use of a indicator (acid insoluble ash [AIA]) $\times$ seven treatments, which consisted of a control diet (CTR); three diets containing phosphate in powder form (PP): $\mathrm{PP}_{\mathrm{A}}=\mathrm{CTR}+$ powder phosphate $\mathrm{A}, \mathrm{PP}_{\mathrm{B}}=\mathrm{CTR}+$ powder phosphate $\mathrm{B}$, and $\mathrm{PP}_{\mathrm{C}}=\mathrm{CTR}+$ powder phosphate $\mathrm{C}$; and another three diets containing the microgranular phosphate (MP): $\mathrm{MP}_{15}=\mathrm{CTR}+$ microgranular phosphate $15 \%, \mathrm{MP}_{45}=\mathrm{CTR}+$ microgranular phosphate $45 \%$ and $\mathrm{MP}_{75}=\mathrm{CTR}+$ microgranular phosphate $75 \%$ ). The values of 15,45 , and $75 \%$ correspond to the watersolubility of the phosphates. There were six replicates, and the pig was considered as experimental unit. The standardized digestibility coefficients of the phosphates assessed by the total collection method, in percent values, were: $\mathrm{PP}_{\mathrm{A}}=86.9, \mathrm{PP}_{\mathrm{B}}=84.9, \mathrm{PP}_{\mathrm{C}}=81.9, \mathrm{MP}_{15}=$ 89.4, $\mathrm{MP}_{45}=88.8$, and $\mathrm{MP}_{75}=92.6$. The standardized-digestibility coefficients of the phosphates evaluated by the indicator method (AIA) in percent values were: $\mathrm{PP}_{\mathrm{A}}=75.9, \mathrm{PP}_{\mathrm{B}}=$ $75.4, \mathrm{PP}_{\mathrm{C}}=75.6, \mathrm{MP}_{15}=84.9, \mathrm{MP}_{45}=78.0$, and $\mathrm{MP}_{75}=79.4$. Considering the two methodologies evaluated in the present work, the microgranular phosphates constitute the best alternative for feeding pigs in the growth phase.

Keywords: fecal indicator, in vitro solubility, minerals, particle size

\section{RESUMO}

Este estudo foi realizado com o objetivo de determinar as digestibilidades aparente e estandardizada de fosfatos para suínos em fase de crescimento, empregando duas metodologias. Foram usados 42 machos castrados, mestiços, com peso inicial de $37 \pm 1,1 \mathrm{~kg}$ em delineamento de blocos casualizados, em esquema fatorial $2 \mathrm{x}$ 7, com dois métodos de coleta: coleta total de fezes e uso de indicador (cinza insolúvel em ácido [AIA ]) $\times$ sete tratamentos, que consistiram de uma dieta controle (CTR); três dietas contendo fosfato na forma de pó (PP): $\mathrm{PPA}=\mathrm{CTR}+$ fosfato pó $\mathrm{A}, \mathrm{PPB}=\mathrm{CTR}+$ fosfato pó $\mathrm{B}$, e PPC $=\mathrm{CTR}+$ fosfato pó $\mathrm{C}$; e mais três dietas contendo $\mathrm{O}$ fosfato microgranular (MP): MP15 = CTR + fosfato microgranular $15 \%, \mathrm{MP} 45=\mathrm{CTR}+$ fosfato microgranular $45 \%$ e MP75 = CTR + fosfato microgranular 75\%). Os valores de 15,45 , e $75 \%$ correspondem à solubilidade em água dos fosfatos. Foram seis repetições, e o animal foi considerado como unidade experimental. Os coeficientes de digestibilidade estandardizada dos fosfatos avaliadas pelo método de coleta total, em valores percentuais, foram: PPA = $86,9, \mathrm{PPB}=84,9, \mathrm{PPC}=81,9, \mathrm{MP} 15=89,4$, 
Rev. Bras. Saúde Prod. Anim., Salvador, v.16, n.3, p.544-557 jul./set.., 2015 http://www.rbspa.ufba.br

MP45 $=88,8$, e MP75 $=92,6$. Os coeficientes de digestibilidade total estandardizada dos fosfatos avaliados pelo método do indicador, em valores percentuais foram: $\mathrm{PPA}=75,9, \mathrm{PPB}=$ $75,4, \mathrm{PPC}=75,6, \mathrm{MP} 15=84,9, \mathrm{MP} 45=78,0, \mathrm{e}$ MP75 = 79,4. Considerando as duas metodologias avaliadas no presente trabalho, os fosfatos microgranulares constituem a melhor alternativa para a alimentação de suínos em fase de crescimento.

Palavras-chave: marcador fecal, solubilidade in vitro, minerais, granulometria

\section{INTRODUCTION}

Among the minerals considered the most relevant in diets for pigs today, special attention has been given to phosphorus $(\mathrm{P})$, which can be found in many chemical sources, with its anion $\mathrm{HPO}_{4}{ }^{2-}$ being the most common form (RICHERT, 2010; ANDERSON et al., 2006). Phosphorus has been recognized as one of the most important minerals in animal nutrition, and considered the third most expensive nutrient in pig diets after the energy and protein sources (FAN et al., 2001; SHURSON \& POMERENKE, 2008; SARAIVA et al., 2012).

Phosphorus levels above the required by pigs may result in excess $P$ in the feces and potential environmental damages. As a consequence, the use of $\mathrm{P}$ in pig diets has to be optimized so as to lower the cost of the diet and the excretion of $P$ in the feces (HANSON et al., 2012).

Diets for pigs are formulated using a large amount of ingredients of plant origin, especially corn and soybean meal, and the digestibility of these nutrients is low, because part of the $\mathrm{P}$ in these plants is bound to the phytic-acid anion, consequently generating the salts of the phytic acid, which is poorly digested by pigs (SELLE \& RAVINDRAN, 2008; ALMEIDA \& STEIN, 2012).
A source of inorganic phosphorus, which has greater availability and digestibility, is commonly added to diets for growing pigs. In this case, therefore, the inorganic $\mathrm{P}$ offsets the low digestibility of the $\mathrm{P}$ found in the form of phytate in plant-derived food sources (PETERSEN et al., 2011).

Some fecal collection methods have been used to determine the digestibility of the nutrients and energy of feeds for monogastric animals. Among these methods are the total collection and the use of fecal indicator (acid insoluble ash, AIA); however, the respective obtained data are still contradictory (CARVALHO et al., 2013). Determining the digestibility by the traditional method of total excreta collection requires strict control of the intake and excretion, which causes this work to be costly (CARVALHO et al., 2013).

Thus, the objective of this study was to determine the apparent and standardized digestibility coefficients of phosphorus according to the phosphate particle sizes by applying two simultaneous methodologies.

\section{MATERIALS AND METHODS}

The experiment was conducted at the Pig Swine Sector of the Animal Science Department of Universidade Federal de Viçosa (UFV), located in Viçosa/MG, Brazil. The experimental period was from October to December 2011.

The experimental procedures were evaluated and approved by the Ethics Committee on the Use of Animals of the Animal Science Department of UFV, protocol no. 27/2011, following the ethical principles of animal experimentation established by the Brazilian College of Animal Experimentation (COBEA, 2011). 
Rev. Bras. Saúde Prod. Anim., Salvador, v.16, n.3, p.544-557 jul./set.., 2015 http://www.rbspa.ufba.br ISSN 15199940

Forty-two crossbred barrows with an initial weight of $37 \pm 1.1 \mathrm{~kg}$ were used in a randomized-block design in a $2 \times 7$ factorial arrangement, with two collection methods: total fecal collection and the use of a indicator (acid insoluble ash [AIA]) and seven diets, which consisted of a control diet (CTR); three diets containing phosphate in powder form (PP): $\mathrm{PP}_{\mathrm{A}}=\mathrm{CTR}+$ powder phosphate $\mathrm{A}, \mathrm{PP}_{\mathrm{B}}=\mathrm{CTR}+$ powder phosphate $\mathrm{B}$, and $\mathrm{PP}_{\mathrm{C}}=\mathrm{CTR}+$ powder phosphate $\mathrm{C}$; and another three diets containing the microgranular phosphate (MP): $\mathrm{MP}_{15}=\mathrm{CTR}+$ microgranular phosphate $15 \%, \quad \mathrm{MP}_{45}=\mathrm{CTR}+$ microgranular phosphate $45 \%$ and $\mathrm{MP}_{75}$ $=\mathrm{CTR}+$ microgranular phosphate $75 \%$ ). The values of $15 ; 45$, and $75 \%$ correspond to the water-solubility of the phosphates. There were six replicates, and one pig was considered one experimental unit.

A control diet was formulated with industrial amino acids, containing $2 \mathrm{~g} / \mathrm{kg}$ dry matter (DM) of phosphorus to meet the nutritional requirements of pigs in the growth phase (ROSTAGNO et al., 2011), except for phosphorus (Table 1).

The treatments consisted of the addition of $2.5 \mathrm{~g}$ of $\mathrm{P} / \mathrm{kg}$ of dry matter (DM), which provided the test phosphates that were added to the control diet. All treatments contained the same amounts of phosphorus $(4.5 \mathrm{~g} / \mathrm{kg} \mathrm{DM}$ of total P) and calcium $(7.0 \mathrm{~g} / \mathrm{kg}$ DM of total $\mathrm{Ca})$, having a $\mathrm{Ca}: \mathrm{P}$ ratio of $1.5: 1$. Ferric oxide was included as a marker at $0.5 \%$ of the diets to indicate the beginning and end of feces collection.

The particle size, chemical composition, and solubility data of the phosphorus (P) sources are presented in Tables 2 and 3.

The animals were individually housed in metabolic cages similar to those described by Pekas (1968). The cages were installed in a shed with concrete floor and masonry walls, provided with exhaust fans and covered with plain tiles. The digestibility trial lasted 12 days, seven of which were considered the period for the animals to acclimate to the cages and experimental diets and to measure intake aiming to determine the metabolic intake, and the other five days were used to collect the feces and urine.

The experimental diets were supplied to the animals in two meals: the first at 08:00 $\mathrm{h}$ and the second at 17:00 $\mathrm{h}$. During the adaptation period, feed was available ad libitum.

During the feces- and urine-collection phase, the daily intake of the experimental diets was based on the metabolic weight $\left(\mathrm{P}^{0.75}\right)$ of the animals considering the lowest intake among the animals in each block, which was determined in the acclimation phase. The feed was moistened, and after it was completely consumed, water was supplied ad libitum.

The feces were directly weighed and homogenized, and a sample of $20 \%$ was conditioned in plastic bags which were labeled and stored in a freezer $\left(18^{\circ} \mathrm{C}\right)$. At the end of the experiment, the samples were thawed at room temperature, homogenized and dried in ventilated ovens at $55^{\circ} \mathrm{C}$ for 72 hours. Subsequently the samples were ground, stored in glass containers and labeled.

Urine was collected every 24 hours. The excreted urine was filtered through a fine nylon-mesh screen to avoid debris which was fixed at the exit of the collector (located under the cage slatted floor) and collected in three plastic buckets containing $20 \mathrm{~mL} \mathrm{HCl} \mathrm{1:1} \mathrm{to}$ prevent bacterial proliferation. After the urine was homogenized and the volume was measured by filtering through a fine sieve, a $150 \mathrm{~mL}$ sample was inserted in a glass container with lid, which was labeled and stored in a 
Rev. Bras. Saúde Prod. Anim., Salvador, v.16, n.3, p.544-557 jul./set.., 2015 http://www.rbspa.ufba.br ISSN 15199940

refrigerator $\left(3^{\circ} \mathrm{C}\right)$. For the laboratory analysis, the stored urine was homogenized again, filtered through gauze, and an aliquot of $50 \mathrm{~mL}$ was collected and placed in a plastic container with lid which was labeled and then maintained under refrigeration for subsequent analysis of phosphorus.

Table 1. Percent composition $(\mathrm{g} / \mathrm{kg} \mathrm{DM})$ of the control diet and the diets with different phosphate sources

\begin{tabular}{|c|c|c|c|c|c|c|c|}
\hline Ingredients & CTR & $\mathrm{PP}_{\mathrm{A}}$ & $\mathrm{PP}_{\mathrm{B}}$ & $\mathrm{PP}_{\mathrm{C}}$ & $\mathrm{MP}_{15}$ & $\mathrm{MP}_{45}$ & $\mathrm{MP}_{75}$ \\
\hline Pre-cooked corn & 420.0 & 420.0 & 420.0 & 420.0 & 420.0 & 420.0 & 420.0 \\
\hline Soybean meal $45 \%$ & 252.1 & 252.1 & 252.1 & 252.1 & 252.1 & 252.1 & 252.1 \\
\hline Sugar & 20.0 & 20.0 & 20.0 & 20.0 & 20.0 & 20.0 & 20.0 \\
\hline Pasta waste & 110.0 & 110.0 & 110.0 & 110.0 & 110.0 & 110.0 & 110.0 \\
\hline Starch & 80.0 & 80.0 & 80.0 & 80.0 & 80.0 & 80.0 & 80.0 \\
\hline Corn $(7.88 \%)$ & 60.0 & 60.0 & 60.0 & 60.0 & 60.0 & 60.0 & 60.0 \\
\hline Soybean oil & 15.0 & 15.0 & 15.0 & 15.0 & 15.0 & 15.0 & 15.0 \\
\hline Limestone & 5.9 & 5.9 & 5.9 & 5.9 & 5.9 & 5.9 & 5.9 \\
\hline Salt & 4.10 & 4.10 & 4.10 & 4.10 & 4.10 & 4.10 & 4.10 \\
\hline Vitamin $\operatorname{mix}{ }^{1}$ & 2.0 & 2.0 & 2.0 & 2.0 & 2.0 & 2.0 & 2.0 \\
\hline Mineral mix ${ }^{2}$ & 1.0 & 1.0 & 1.0 & 1.0 & 1.0 & 1.0 & 1.0 \\
\hline L-lysine & 3.7 & 3.7 & 3.7 & 3.7 & 3.7 & 3.7 & 3.7 \\
\hline DL-methionine & 0.6 & 0.6 & 0.6 & 0.6 & 0.6 & 0.6 & 0.6 \\
\hline L-threonine & 5.0 & 5.0 & 5.0 & 5.0 & 5.0 & 5.0 & 5.0 \\
\hline Choline chloride & 5.0 & 5.0 & 5.0 & 5.0 & 5.0 & 5.0 & 5.0 \\
\hline BHT & 0.1 & 0.1 & 0.1 & 0.1 & 0.1 & 0.1 & 0.1 \\
\hline $\begin{array}{l}\text { Acid-insoluble ash (AIA) - } \\
\left.\text { Celite }^{(}\right)\end{array}$ & 10.0 & 10.0 & 10.0 & 10.0 & 10.0 & 10.0 & 10.0 \\
\hline Starch & 14.4 & 0.7 & 0.5 & 1.8 & 1.3 & 1.9 & 2.6 \\
\hline Phosphates $^{3}$ & & 13.7 & 13.9 & 12.6 & 13.1 & 12.5 & 11.8 \\
\hline Total & $1,000.0$ & $1,000.0$ & $1,000.0$ & $1,000.0$ & $1,000.0$ & $1,000.0$ & $1,000.0$ \\
\hline \multicolumn{8}{|l|}{ Calculated composition } \\
\hline Crude protein & 170.0 & 170.0 & 170.0 & 170.0 & 170.0 & 170.0 & 170.0 \\
\hline $\mathrm{ME}(\mathrm{Kcal} / \mathrm{kg})$ & 3,347 & 3,341 & 3,341 & 3,341 & 3,341 & 3,341 & 3,341 \\
\hline Digestible lysine & 10.49 & 10.49 & 10.49 & 10.49 & 10.49 & 10.49 & 10.49 \\
\hline Digestible met. + cys. & 5.47 & 5.47 & 5.47 & 5.47 & 5.47 & 5.47 & 5.47 \\
\hline Digestible threonine & 6.03 & 6.03 & 6.03 & 6.03 & 6.03 & 6.03 & 6.03 \\
\hline Sodium & 1.8 & 1.8 & 1.8 & 1.8 & 1.8 & 1.8 & 1.8 \\
\hline Calcium & 3.0 & 7.0 & 7.0 & 7.0 & 7.0 & 7.0 & 7.0 \\
\hline Phosphorus & 2.0 & 4.5 & 4.5 & 4.5 & 4.5 & 4.5 & 4.5 \\
\hline
\end{tabular}

${ }^{1}$ Composition per kg: vit. A - 9,000,000 IU; vit. D3 - 1,500,000 IU; vit. E - 10,000 IU; vit. B1, 2g; vit. B2, 5g; vit. B6 - 30g; pantothenic acid - 25g; vit. K3 - 4g; vit. B12 - 40mg; nicotinic acid - 40g; antioxidant - $30 \mathrm{~g}$; selenium - $23 \mathrm{mg}$; excipient q.s. $-1,000 \mathrm{~g}$.

${ }^{2}$ Composition per kg: $\mathrm{Fe}-180 \mathrm{~g}$; Cu - 20g; Co - 4g; $\mathrm{Mn}-80 \mathrm{~g}$; Zn - 140g; I - 4 g; excipient q.s. - 1,000g.

${ }^{3}$ Inclusion of the following phosphates: $\mathrm{PP}_{\mathrm{A}}=$ powder phosphate $\mathrm{A} ; \mathrm{PP}_{\mathrm{B}}=$ powder phosphate $\mathrm{B} ; \mathrm{PP}_{\mathrm{C}}=$ powder phosphate $\mathrm{C} ; \mathrm{MP}_{15}=$ microgranular phosphate $15 \% ; \mathrm{MP}_{45}=$ microgranular phosphate $45 \%$ and $\mathrm{MP}_{75}=$ microgranular phosphate $75 \%$. 
Rev. Bras. Saúde Prod. Anim., Salvador, v.16, n.3, p.544-557 jul./set.., 2015 http://www.rbspa.ufba.br ISSN 15199940 http://dx.doi.org/10.1590/S1519-99402015000300007

Table 2. Distribution of particle size and geometric mean diameter (GMD) of the phosphorus sources ${ }^{1}$

\begin{tabular}{lccccccc}
\hline \multirow{2}{*}{ Sieve number - diameter } & \multirow{2}{*}{ Unit } & \multicolumn{5}{c}{ Phosphorus sources $^{2}$} \\
\cline { 3 - 7 } & & $\mathrm{PP}_{\mathrm{A}}$ & $\mathrm{PP}_{\mathrm{B}}$ & $\mathrm{PP}_{\mathrm{C}}$ & $\mathrm{MP}_{15}$ & $\mathrm{MP}_{45}$ & $\mathrm{MP}_{75}$ \\
\hline \# 09-2.00 mm & \% retained & 0.07 & 0.02 & 0 & 0 & 0 & 0 \\
$\# 12-1.41 \mathrm{~mm}$ & \% retained & 0.61 & 0.34 & 0.16 & 3.6 & 4.8 & 1.37 \\
$\# 20-0.84 \mathrm{~mm}$ & \% retained & 2.17 & 3.18 & 9.97 & 17.5 & 22.1 & 30.1 \\
$\# 35-0.50 \mathrm{~mm}$ & \% retained & 5.4 & 10.3 & 29 & 30.3 & 26.9 & 54.5 \\
$\# 60-0.25 \mathrm{~mm}$ & \% retained & 8.7 & 13.1 & 20.5 & 17.2 & 17.5 & 11.3 \\
\# 100-0.15 mm & \% retained & 12 & 14.7 & 8.21 & 8.3 & 13 & 1.79 \\
GMD & $\mu \mathrm{m}$ & 415.07 & 438.33 & 634.66 & 767.51 & 756.08 & 944.68
\end{tabular}

${ }^{1}$ Analyses conducted at the laboratory of Rodes Química Cajati LTDA in Cajati/SP.

${ }^{2} \mathrm{PP}_{\mathrm{A}}=$ powder phosphate $\mathrm{A} ; \mathrm{PP}_{\mathrm{B}}=$ powder phosphate $\mathrm{B} ; \mathrm{PP}_{\mathrm{C}}=$ powder phosphate $\mathrm{C} ; \mathrm{MP}_{15}=$ microgranular phosphate $15 \% ; \mathrm{MP}_{45}=$ microgranular phosphate $45 \%$ and $\mathrm{MP}_{75}=$ microgranular phosphate $75 \%$.

Table 3. Chemical composition, solubility and ratio between minerals in the phosphorus sources

\begin{tabular}{|c|c|c|c|c|c|c|c|}
\hline \multirow{2}{*}{ Chemical composition } & \multicolumn{7}{|c|}{ Phosphorus sources $^{1}$} \\
\hline & Unit & $\mathrm{PP}_{\mathrm{A}}$ & $\mathrm{PP}_{\mathrm{B}}$ & $\mathrm{PP}_{\mathrm{C}}$ & $\mathrm{MP}_{15}$ & $\mathrm{MP}_{45}$ & $\mathrm{MP}_{75}$ \\
\hline Total P & $\%$ & 18.3 & 18.0 & 19.9 & 19.1 & 20.0 & 21 \\
\hline Cit. acid $2 \%$-soluble P & $\%$ & 93.0 & 84.2 & 94.6 & 89.1 & 94 & 88.8 \\
\hline Water-soluble P & $\%$ & 8.0 & 12.0 & 4.0 & 15 & 45 & 75 \\
\hline $\mathrm{Ca}$ & $\%$ & 20.8 & 24.0 & 23.6 & 21.1 & 18.4 & 14.7 \\
\hline $\mathrm{Fe}$ & $\%$ & 0.43 & 0.72 & 1.13 & 0.44 & 0.58 & 0.82 \\
\hline $\mathrm{Mg}$ & $\%$ & 2.16 & 4.45 & 0.45 & 2.26 & 1.4 & 0.63 \\
\hline $\mathrm{Ca}: \mathrm{P}$ & & $1.14: 1$ & $1.33: 1$ & $1.19: 1$ & $1.1: 1$ & 0.92:1 & $0.71: 1$ \\
\hline$P: F$ & & $135: 1$ & $130: 1$ & $221: 1$ & $143: 1$ & $69: 1$ & $160: 1$ \\
\hline $\mathrm{F}$ & $\mathrm{mg} / \mathrm{kg}$ & 1.358 & 1.388 & 900 & 1.338 & 2.900 & 1.309 \\
\hline $\mathrm{Mn}$ & $\mathrm{mg} / \mathrm{kg}$ & 687 & 618 & 544 & 700 & 469 & 270 \\
\hline $\mathrm{Zn}$ & $\mathrm{mg} / \mathrm{kg}$ & 30.5 & 72.7 & 150 & 32.7 & 36 & 92.7 \\
\hline $\mathrm{Cu}$ & $\mathrm{mg} / \mathrm{kg}$ & 16.4 & 81.7 & 115 & 15.2 & 40 & 9.07 \\
\hline $\mathrm{Co}$ & $\mathrm{mg} / \mathrm{kg}$ & 15.6 & 22.9 & 21.1 & 14.2 & 9.2 & 9.97 \\
\hline
\end{tabular}

The mineral contents in the phosphates were determined and the solubility tests were performed at the laboratory of Rodes Química Cajati Ltda., in Cajati/SP, according to methodologies described by the Brazilian Animal Feeding Compendium (CBAA, 2009). The dry matter (DM), ash and fecal indicator were analyzed at the laboratory of Animal Nutrition of the
Animal Science Department (DZO) of UFV according to the methodologies described by CBAA (2009).

The geometric mean diameter (GMD) of the particles of the phosphates were determined from the analyses conducted at the laboratory of Química Cajati Ltda, in Cajati/SP, according to the methodology described by Butolo (2010), with 2.00, 1.41, 0.84, 0.50, 0.25, 
Rev. Bras. Saúde Prod. Anim., Salvador, v.16, n.3, p.544-557 jul./set.., 2015 http://www.rbspa.ufba.br

and $0.15 \mathrm{~mm}$ sieves. The amounts retained in the sieves were recorded for the calculation of the GMD.

The environment temperature was recorded daily by analogical thermometers of maximum and minimum temperature, and the relative air humidity was determined using a dry and wet bulb analogical thermometer. The thermometers of maximum and minimum temperatures were placed at two different points of the shed, and the dry and wetbulb thermometer was installed in the middle part of the shed. All thermometers were installed in an environment external to the cages at half height of the body of the animals.

The intakes of feed $(\mathrm{g})$, dry matter $(\mathrm{g})$ and total $\mathrm{P}$ from the control diet and treatments (g) were determined. The phosphorus supplied through the control diet and the treatments $(\%)$, the $\mathrm{P}$ content in the diets and feces (\%), the $\mathrm{P}$ excretion $(\mathrm{g})$, the indigestibility factor, the excreted $\mathrm{P}$ from control diet and treatments $(\%)$, the ash, and the acid insoluble ash (AIA) were also determined. These data were used in the adapted equations by Petersen \& Stein (2006) and Rostagno \& Featherston (1977) to determine the apparent digestibility coefficients of $\mathrm{P}$, from the treatments by the two methods evaluated in the present study.

1-Total-collection method:

*Apparent fecal digestibility (AFD) of P (PETERSEN \& STEIN, 2006).

$$
\operatorname{AFD}(\%)=((\mathrm{P} \text { intake }(\mathrm{g})-\mathrm{P} \text { feces }(\mathrm{g}) \times 100)) / \mathrm{P} \text { intake }(\mathrm{g})
$$

2-Acid-insoluble ash (ASH) indicator method:

*Indigestibility factor (IF): IF $=\%$ AIA diet $/ \%$ AIA feces
*Apparent fecal digestibility (AFD) of $P$ (adapted from ROSTAGNO \& FEATHERSTON, 1977).

$$
\text { AFD of } \mathrm{P}(\%)=((\% \mathrm{P} \text { diet }-(\% \mathrm{P} \text { feces } \times \mathrm{IF})) \times 100) / \% \mathrm{P} \text { diet }
$$

The concentration of standardized digestible phosphorus $(\mathrm{P})$ of the treatments should be determined by applying the correction of the endogenous $\mathrm{P}$ excreted and transforming the apparent digestible $\mathrm{P}$ content into standardized digestible $\mathrm{P}$ content (ROSTAGNO et al., 2011).

The standardized fecal digestibility (SFD) values were calculated by the correction of the endogenous losses of the control diet (BAKER, 2011). The endogenous losses of the control diet utilized for the calculation of the standardized fecal digestibility (SFD) of the $\mathrm{P}$ in the diets and in the phosphates were $258 \mathrm{mg} \mathrm{P} / \mathrm{kg}$ of ingested dry matter (ROSTAGNO et al., 2011).

The standardized fecal digestibility (SFD) values of $\mathrm{P}$ are calculated by subtracting the fraction corresponding to the basal endogenous losses from the total $\mathrm{P}$ output, according to the following equation (ALMEIDA \& STEIN, 2010):

$$
\text { SFD of } \mathrm{P}(\%)=[(\mathrm{Pi}-(\mathrm{Pf}-\mathrm{Pe})) / \mathrm{Pi}] \times 100,
$$

Where $\mathrm{Pi}=$ Total $\mathrm{P}$ intake, as $\mathrm{g} ; \mathrm{Pf}=\mathrm{P}$ excreted in feces, as $\mathrm{g}$; $\mathrm{Pe}=$ basal endogenous losses as grams per day $(\mathrm{g} / \mathrm{d})$ or as grams $(\mathrm{g})$ in the experimental period set.

The retained $\mathrm{P}$ values were calculated 
Rev. Bras. Saúde Prod. Anim., Salvador, v.16, n.3, p.544-557 jul./set.., 2015 http://www.rbspa.ufba.br

by the following equation (PETERSEN \& STEIN, 2006):

$\mathrm{Pr}=([\mathrm{Pi}-\{\mathrm{Pf}+\mathrm{Pu}\}] / \mathrm{Pi}) \times 100$,

Where $\mathrm{Pr}=$ retained $\mathrm{P}$, as $\% ; \mathrm{Pu}=\mathrm{P}$ excreted in urine, as $\mathrm{g}$.

The parameters were statistically analyzed using the SAEG program version 9.1 (UFV, 2001), and the data were subjected to variance analysis. Means of the main factors and interactions were compared by Tukey's test at $5 \%$.

\section{RESULTS AND DISCUSSION}

The maximum and minimum temperatures recorded during the experimental period were $26.1 \pm 2.35$ and $21.9 \pm 1.19{ }^{\circ} \mathrm{C}$, respectively, and the average relative air humidity was $86.4 \pm$ $6.92 \%$.

According to Baêta (1997), the minimum and maximum temperatures, which correspond to the thermal comfort zone for the growth phase, would be 18 and $26^{\circ} \mathrm{C}$, respectively. Thus, in the present study, the maximum temperature $(26.1 \pm$ $2.35^{\circ} \mathrm{C}$ ) was observed to be at the limit of the comfort zone (upper limit of $26^{\circ} \mathrm{C}$ ). However, such values are below the upper critical temperature, which, for this category, is $27^{\circ} \mathrm{C}$. The observed average relative air humidity $(86.4 \pm 6.92 \%)$ was higher than the recommended parameters for rearing pigs (60 to $80 \%$ ) (NÄÄS, 1997).

It was observed that there are differences in GMD among the powder phosphates from the different manufacturers and among the microgranular phosphates. The dicalcium phosphates in powder form, except $\mathrm{PP}_{\mathrm{C}}$, had a greater percentage of grains below $0.15 \mathrm{~mm}$. Thus, the fineness of the dicalcium phosphate should also be taken into account, given that this parameter affects the digestibility of the $\mathrm{P}$ element (POTTER, 1988).

The lowest calcium: phosphorus ratio was observed in $\mathrm{MP}_{75}$. The highest concentration of fluorine was found in $\mathrm{MP}_{45}$. The ancillary elements present in the phosphates can vary significantly depending of the type of product, or even in a single type of phosphate, depending on the phosphate rock used in the industry and/or its manufacturing route (CHEN et al., 2007). Analyzing different commercial brands, Teixeira et al. (2005) found large variations in the mineral profile of phosphates commercialized in Brazil.

The intake dry matter and digestibility values according to the particle size and solubility of the phosphorus sources can be seen in Table 4. The phosphorus sources did not affect $(\mathrm{P}>0.05)$ the dry matter digestibility coefficient.

Table 4. Apparent dry matter digestibility coefficient (DMDC) by total collection method in the diets ${ }^{1}$

\begin{tabular}{|c|c|c|c|c|c|c|c|c|c|c|}
\hline \multirow{2}{*}{ Parameters } & \multicolumn{9}{|c|}{ Phosphorus sources $^{2}$} & \multirow{2}{*}{$\begin{array}{l}\mathrm{CV} \\
(\%)\end{array}$} \\
\hline & CTR & $\mathrm{PP}_{\mathrm{A}}$ & $\mathrm{PP}_{\mathrm{B}}$ & $\mathrm{PP}_{\mathrm{C}}$ & Mean & $\mathrm{MP}_{15}$ & $\mathrm{MP}_{45}$ & $\mathrm{MP}_{75}$ & Mean & \\
\hline DM intake $(\mathrm{kg} / \mathrm{d})$ & 1,279 & 1,272 & 1,268 & 1,263 & 1,268 & 1,250 & 1,254 & 1,278 & 1,252 & 8.5 \\
\hline Feces $(g / d)$ & 78.1 & 66.7 & 73.7 & 70.9 & 70.4 & 73.0 & 64.4 & 68.0 & 66.7 & 16.8 \\
\hline DMDC $(\%)$ & 93.9 & 94.7 & 94.2 & 94.3 & 94.41 & 94.1 & 94.8 & 94.7 & 94.6 & 0.9 \\
\hline
\end{tabular}

${ }^{1}(\mathrm{P}<0.05)$ Means followed by different letters in the row differ by Tukey's test.

${ }^{2} \mathrm{PP}_{\mathrm{A}}=$ powder phosphate $\mathrm{A} ; \mathrm{PP}_{\mathrm{B}}=$ powder phosphate $\mathrm{B} ; \mathrm{PP}_{\mathrm{C}}=$ powder phosphate $\mathrm{C} ; \mathrm{MP}_{15}=$ microgranular phosphate $15 \% ; \mathrm{MP}_{45}=$ microgranular phosphate $45 \%$ and $\mathrm{MP}_{75}=$ microgranular phosphate $75 \%$. 
Rev. Bras. Saúde Prod. Anim., Salvador, v.16, n.3, p.544-557 jul./set.., 2015 http://www.rbspa.ufba.br ISSN 15199940

The results obtained herein were different from those reported by Lindemann et al. (2010), who found a DMDC of $91.7 \%$ working with pigs in the growth phase. Dilger \& Adeola (2006) found high DMDC values for pigs in the same phase, varying from $94.1 \%$ to $97.3 \%$.

The results of the trial evaluating the digestibility of the phosphorus in the phosphate according to the collection methodology adopted are shown in Table 5.

Table 5. Parameters related to the metabolism of the phosphorus from different phosphates and coefficients of apparent fecal digestibility (AFD) and standardized fecal digestibility (SFD) by the methods of total collection and fecal indicator ${ }^{1}$

\begin{tabular}{|c|c|c|c|c|c|c|c|c|c|c|c|}
\hline \multirow[b]{2}{*}{ Parameters } & \multicolumn{10}{|c|}{ Treatments } & \multirow{2}{*}{$\begin{array}{l}\text { CV } \\
(\%)\end{array}$} \\
\hline & Unit & CTR & $\mathrm{PP}_{\mathrm{A}}$ & $\mathrm{PP}_{\mathrm{B}}$ & $\mathrm{PP}_{\mathrm{C}}$ & Mean & $\mathrm{MP}_{15}$ & $\mathrm{MP}_{45}$ & $\mathrm{MP}_{75}$ & $\begin{array}{c}\text { Mea } \\
\mathrm{n}\end{array}$ & \\
\hline Initial weight & $\mathrm{Kg}$ & 37.4 & 37.2 & 37.1 & 37.2 & 37.1 & 36.4 & 36.9 & 36.5 & 36.6 & 20.7 \\
\hline$P$ intake & $\mathrm{g} / \mathrm{d}$ & 2.6 & 5.8 & 5.7 & 5.5 & 5.7 & 5.7 & 5.7 & 5.9 & 5.8 & 7.6 \\
\hline$P$ feces & $\mathrm{g} / \mathrm{d}$ & 1.7 & 2.5 & 2.6 & 2.5 & $2.5^{\mathrm{A}}$ & 2.4 & 2.1 & 2.1 & $2.2^{\mathrm{B}}$ & 14.8 \\
\hline P urine & $\mathrm{g} / \mathrm{d}$ & 0.1 & 0.1 & 0.1 & 0.1 & 0.1 & 0.1 & 0.1 & 0.1 & 0.1 & 64.3 \\
\hline Endogenous $\mathrm{P}$ & $\mathrm{g} / \mathrm{d}$ & 0.3 & 0.3 & 0.3 & 0.3 & 0.3 & 0.3 & 0.3 & 0.3 & 0.3 & 8.7 \\
\hline Retained P & $\%$ & 35.0 & 56.2 & 55.1 & 54.8 & $55.4^{\mathrm{B}}$ & 56.8 & 61.3 & 62.0 & $60.0^{\mathrm{A}}$ & 11.8 \\
\hline \multicolumn{12}{|c|}{ Total fecal collection method } \\
\hline AFD diet & $\%$ & 35.6 & 57.4 & 56.0 & 55.6 & $56.3^{\mathrm{B}}$ & 57.7 & 62.3 & 62.8 & $60.9^{\mathrm{A}}$ & 11.2 \\
\hline SFD diet & $\%$ & 46.8 & 62.4 & 61.0 & 60.6 & $61.3^{\mathrm{B}}$ & 62.6 & 67.3 & 67.8 & $65.9^{\mathrm{A}}$ & 10.4 \\
\hline $\begin{array}{l}\text { SFD } \\
\text { phosphates }\end{array}$ & $\%$ & - & 86.9 & 84.9 & 81.9 & $84.6^{\mathrm{B}}$ & 89.4 & 88.8 & 92.6 & $90.3^{\mathrm{A}}$ & 10.1 \\
\hline \multicolumn{12}{|c|}{ Fecal indicator method } \\
\hline AFD diet & $\%$ & 38.6 & $61.3^{\mathrm{a}}$ & $55.8^{\mathrm{b}}$ & $53.3^{\mathrm{b}}$ & $56.8^{\mathrm{B}}$ & 65.5 & 62.2 & 65.1 & $64.3^{\mathrm{A}}$ & 8.8 \\
\hline SFD diet & $\%$ & 44.4 & $63.6^{\mathrm{a}}$ & $58.3^{\mathrm{b}}$ & $56.0^{\mathrm{b}}$ & $59.3^{\mathrm{B}}$ & 67.8 & 64.4 & 67.1 & $66.4^{\mathrm{A}}$ & 8.4 \\
\hline $\begin{array}{l}\text { SFD } \\
\text { phosphates }\end{array}$ & $\%$ & - & 75.9 & 75.4 & 75.6 & $75.6^{\mathrm{B}}$ & 84.9 & 78.0 & 79.4 & $80.8^{\mathrm{A}}$ & 8.3 \\
\hline
\end{tabular}

There was no interaction $(\mathrm{P}>0.05)$ between the phosphorus sources and the collection methodologies utilized in this experiment.

Several parameters were not affected $(\mathrm{P}>0.05)$ by the phosphorus sources, e.g. $\mathrm{P}$ intake, $\mathrm{P}$ excreted in the feces and urine, endogenous $\mathrm{P}$, retained $\mathrm{P}$, apparent fecal digestibility of $\mathrm{P}$, or standardized fecal digestibility of $\mathrm{P}$. These parameters were determined in the diets by the total fecal collection method.
The phosphorus intake by the animals that consumed the control diet was, on average, $2.6 \mathrm{~g} / \mathrm{d}$. For the treatments that included a supplemental source of $\mathrm{P}$ from the powder phosphates and from the microgranular phosphates, the $\mathrm{P}$ intake was 5.7 and $5.8 \mathrm{~g} / \mathrm{d}$, respectively. These average results of 5.7 and $5.8 \mathrm{~g} / \mathrm{d}$ were similar to those obtained by Stein et al. (2008), who worked with pigs weighing $22 \mathrm{~kg}$, on average, using monocalcium phosphate with $15.6 \% \mathrm{Ca}$ and $21.0 \% \mathrm{P}$, and obtained an average $\mathrm{P}$ 
Rev. Bras. Saúde Prod. Anim., Salvador, v.16, n.3, p.544-557 jul./set.., 2015 http://www.rbspa.ufba.br ISSN 15199940

intake of $5.2 \mathrm{~g} / \mathrm{d}$. Those results are associated with the level of $\mathrm{P}$ in the diet (TEIXEIRA et al., 2004).

The amount phosphorus excreted in the feces was found to decrease between the powder and microgranular phosphate treatments $(\mathrm{P}<0.05)$, with the lowest excretion occurring when the phosphate was in microgranular form.

The phosphorus excreted in the urine was not affected $(\mathrm{P}>0.05)$ by the supplemental $\mathrm{P}$ sources, which is in disagreement with the data presented by Teixeira et al. (2004) and Bünzen (2009), who observed that the P content in the feces and urine increased with the level of $\mathrm{P}$ in the diet.

The estimated endogenous $\mathrm{P}$ values were similar $(\mathrm{P}>0.05)$ among the treatments. The results are close to those shown by Jongbloed et al. (1992), who reported that the endogenous fecal $\mathrm{P}$ for pigs varies from 5 to $10 \mathrm{mg} \mathrm{P} / \mathrm{kg}$ of live weight/d.

Working with $31 \mathrm{~kg}$ pigs, Dilger \& Adeola (2006), obtained endogenous losses of $4.8 \mathrm{mg} /\left(\mathrm{kg} \mathrm{P} \mathrm{P}^{0.75} \times\right.$ day $)$, similar to the 9 and $7 \mathrm{mg} /\left(\mathrm{kg} \mathrm{P}^{0.75} \times\right.$ day $)$ found by Pettey et al. (2006) with animals weighing 27 and $59 \mathrm{~kg}$, respectively. These values were lower than the 28 and $56 \mathrm{mg} /\left(\mathrm{kg} \mathrm{P}^{0.75} \times\right.$ day $)$ obtained by Fan et al. (2001) and Ajakaiye et al. (2003) with 14- and 49-kg animals, respectively. This value oscillates among the observed values of 139,174 , 232, 258 and $310 \mathrm{mg} \mathrm{P} / \mathrm{kg}$ DM intake by animals fed diets without $P$ (PETERSEN \& STEIN, 2006; BAKER, 2011; TEIXEIRA et al., 2004; BÜNZEN, 2009; FAN et al., 2001).

The retained $\mathrm{P}$ was lower $(\mathrm{P}<0.05)$ in the animals that consumed CTR compared with other treatments. It was positively correlated with the $\mathrm{P}$ intake, i.e., the increase in retained $\mathrm{P}$ is directly proportional to its intake.
The standardized digestibility of the phosphorus from the control diet (CTR) was 46.8 and 44.4 for the totalcollection and fecal-indicator methods, respectively. Dilger \& Adeola (2006) found $46.5 \%$ for the apparent digestibility of a diet without an inorganic $P$ source. This value was determined using the fecal-indicator method, with chromic oxide, in $18 \mathrm{~kg}$ pigs. Almeida \& Stein (2012) evaluated the digestibility of corn in diets for pigs in the growth phase with an initial weight of $18.2 \mathrm{~kg}$ and obtained an apparent digestibility of $\mathrm{P}$ of $33.5 \%$ and standardized fecal digestibility of $40.9 \%$. A study conducted with pigs with an initial body weight of $14 \mathrm{~kg}$ fed a diet based on soybean meal, corn starch and sucrose reported apparent and standardized fecal digestibilities of 41.6 and $46.1 \%$, respectively (ROJAS \& STEIN, 2012).

Working with pigs with an initial weight of $9.2 \mathrm{~kg}$ fed a diet based on corn starch, whey powder and sucrose, the results for apparent and standardized fecal digestibilities of $\mathrm{P}$ were $84.3 \%$ and $91.2 \%$, respectively (KIM et al., 2012).

In an experiment with pigs with an initial body weight of $27 \mathrm{~kg}$, Petersen \& Stein (2006) found apparent and true digestibility values of 81.49 and $88.41 \%$, respectively, but they used a diet containing $30 \%$ gelatin, $40 \%$ corn starch and $19 \%$ sucrose.

The standardized digestibility coefficients of phosphates evaluated by the total collection method, as percentage $(\%)$, were $\mathrm{PP}_{\mathrm{A}}=86.9, \mathrm{PP}_{\mathrm{B}}=$ $84.9, \mathrm{PP}_{\mathrm{C}}=81.9, \mathrm{MP}_{15}=89.4, \mathrm{MP}_{45}=$ 88.8 , and $\mathrm{MP}_{75}=92.6$.

By the fecal-indicator methodology, there were differences $(\mathrm{P}<0.05)$ between the apparent fecal digestibility of $\mathrm{P}$ and the standardized digestibility of $\mathrm{P}$ in the diets containing powder phosphate from different companies, 
Rev. Bras. Saúde Prod. Anim., Salvador, v.16, n.3, p.544-557 jul./set.., 2015 http://www.rbspa.ufba.br

with greater values $(\mathrm{P}<0.05)$ observed for $\mathrm{PP}_{\mathrm{A}}$ compared with the other two.

The standardized fecal digestibility coefficients of the phosphates were greater in the present study than to those obtained by several authors who worked with pigs in the growth phase. More precisely, these authors found apparent digestibility values for dicalcium phosphate of 63\% (EEKHOUT \& De PAEPE, 1996) and 66\% (KEMME et al., 1993). However, Bünzen (2009) found apparent and true digestibility coefficients of $P$ of 74.65 and $74.79 \%$, respectively, in a dicalcium phosphate with $18.5 \%$ total $P$.

Working with pigs in the growth phase (with an average weight of $28.95 \mathrm{~kg}$ ) with the isotopic-dilution technique, Teixeira et al. (2004) found $89.44 \%$ for the bioavailability of $\mathrm{P}$ from dicalcium phosphate, which contained $18.66 \% \mathrm{P}$. In a study conducted with pigs whose initial weight was $34.9 \mathrm{~kg}$ evaluating dicalcium phosphate with $19.77 \% \mathrm{P}$, the apparent fecal digestibility was $86.1 \%$, and the standardized digestibility was 93.1\% (BAKER, 2011). Thus, there are variations among the different phosphates and in the same product from different origins. These differences are attributed to the composition, the processing and the physical structure in which the evaluated phosphates are presented (BÜNZEN, 2009).

The total fecal collection method showed the highest values $(\mathrm{P}<0.05)$ for the standardized digestibility coefficients of the phosphates compared with the use of fecal indicator. Additionally, lower variability of the data can be observed when the fecal indicator acid-insoluble ash (AIA) is used. Such results are corroborated by the data obtained by Kavanagh et al. (2001), who, evaluating growing pigs, verified that AIA is a fast and reliable indicator to measure digestibility, serving as an alternative to the total collection method. However, Bünzen (2005), working with total collection or chromic oxide as fecal indicator, did not obtain differences evaluating the digestibility coefficients of $\mathrm{P}$ in different phosphates.

By the two studied methods, it can be observed that the particle size affected $(\mathrm{P}<0.05)$ the $\mathrm{P}$ in the feces, the retained $\mathrm{P}$ and the apparent and standardized fecal digestibilities. Jongbloed \& Kemme (1990) did not observe significant differences regarding the influence of particle size on the digestibility of the $\mathrm{P}$ from diets to swine based on corn and soybean meal.

The standardized digestibility coefficients of the phosphates evaluated by the indicator (AIA) method, as percentage $(\%)$ were: $\mathrm{PP}_{\mathrm{A}}=75.9, \mathrm{PP}_{\mathrm{B}}=$ 75.4, $\mathrm{PP}_{\mathrm{C}}=75.6, \mathrm{MP}_{15}=84.9, \mathrm{MP}_{45}=$ 78.0 and $\mathrm{MP}_{75}=79.4$.

The lower digestibility coefficients obtained for the powder phosphates in relation to the microgranular phosphates evaluated in the current study are likely related to a greater water-solubility of the mono-dicalcium phosphate in relation to dicalcium phosphate (BUNZEN, 2005). Undoubtedly, phosphates highly soluble in water cannot be commercialized in powder form due to their chemical instability, which can cause embedment of the mineral mix.

The standardized fecal digestibility values of the different phosphates evaluated were different between the methods employed, but both methodologies can be used to determine the digestibility of this mineral in diets for pigs.

Considering the two methodologies evaluated in the present work, the microgranular phosphates are the best alternative for feeding pigs in the growth phase. 
Rev. Bras. Saúde Prod. Anim., Salvador, v.16, n.3, p.544-557 jul./set.., 2015 http://www.rbspa.ufba.br ISSN 15199940

\section{ACKNOWLEDGMENTS}

We thank FAPEMIG for financing the project and the staff from the Department of Animal Science/UFSJ and from the Department of Animal Science/UFV involved in this study.

\section{REFERENCES}

AJAKAIYE, A.; FAN, M.Z.;

ARCHBOLD, T.; HACKER, R.R.; FORSBERG, C.W.; PHILLIPS, J.P. Determination of true digestive utilization of phosphorus and the endogenous phosphorus outputs associated with soybean meal of growing pigs. Journal of Animal Science, v.81, p.2766-2775, 2003.

ALMEIDA, F.N.; STEIN, H.H.

Performance and phosphorus balance of pigs fed diets formulated on the basis of values for standardized total tract digestibility of phosphorus. Journal of Animal Science, v.88, p.2968-2977, 2010.

ALMEIDA, F.N.; STEIN, H.H. Effects of graded levels of microbial phytase on the standardized total tract digestibility of phosphorus in corn and corn coproducts fed to pigs. Journal of Animal Science, v.90, p.1262-1269, 2012.

ANDERSON, J.J.B.; KLEMMER, P.J.; WATTS, M.L.S.; GARNER, S.C.; CALVO, M.S. Phosphorus. In: BOWMAN, B.A.; RUSSELL, R.M. (Eds.). Present Knowledge in Nutrition. Washington: Life Sciences Inst., 2006. p.383-400.

BAÊTA, F.C. Ambiência em edificações rurais: conforto animal. Viçosa, MG: Universidade Federal de Viçosa, 1997. 246 p.
BAKER, S.R. Aspects of phosphorus nutrition in swine. 2011. 105p. Thesis (Master of Science in Animal Sciences) University of Illinois at UrbanaChampaign, Champaign.

BÜNZEN, S. Digestibilidade aparente e verdadeira do fósforo de alimentos determinada com suínos em crescimento e em terminação. 2005. 72p. Dissertação (Mestrado em Nutrição de Monogástrico) - Universidade Federal de Viçosa, Viçosa.

BÜNZEN, S. Digestibilidade do fósforo de alimentos e exigência de fósforo digestível de aves e suínos. 2009. 129p. Tese (Doutorado em Nutrição de Monogástrico) Universidade Federal de Viçosa, Viçosa.

BUTOLO, J.E. Qualidade de ingredientes na alimentação animal. Campinas, SP: CBNA, 2010. 430p.

COMPÊNDIO BRASILEIRO DE ALIMENTAÇÃO ANIMAL - CBAA. Guia de métodos analíticos. São Paulo: Sindirações, 2009. 217p.

CARVALHO, G.B.; DOURADO, L.R.B.; LOPES, J.B.; FERREIRA, A.H.C.; RIBEIRO, M.N.; SILVA, S.R.G.; MERVAL, R.R.; BIAGIOTTI, D.; SILVA, F.E.S. Métodos de análise da cinza insolúvel em ácido utilizada como indicador na determinação da energia metabolizável do milho para aves. Revista Brasileira de Saúde e Produção Animal [online], v.14, p.4353, 2013.

CHEN, W.; CHANG, A.C.; WU, L. Assessing long-term environmental risks of trace elements in phosphate fertilizers. Ecotoxicology and Environmental Safety, v.67, p.48-58, 2007. 
Rev. Bras. Saúde Prod. Anim., Salvador, v.16, n.3, p.544-557 jul./set.., 2015 http://www.rbspa.ufba.br ISSN 15199940

COLÉGIO BRASILEIRO DE EXPERIMENTAÇÃO ANIMAL COBEA. Animais de laboratório.

Disponível em:

$<\mathrm{http}: / /$ www.cobea.org.br>. Acesso em: $05 \mathrm{dez} .2011$.

DILGER, R.N.; ADEOLA, O. Estimation of true phosphorus digestibility and endogenous phosphorus loss in growing pigs fed conventional and low-phytate soybean meals. Journal of Animal Science, v.84, p.627-634, 2006.

EEKHOUT, W.; De PAEPE, M. The digestibility of three calcium phosphates for pigs as measured by difference and by slope-ratio assay. Journal of Animal Physiology and Animal Nutrition, v.77, p.53-60, 1997.

FAN, M.Z.; ARCHBOLD, T.; SAUER, W.C.; LACKEYRAM, D.; RIDEOUT, T.; GAO, Y.; DE LANGE; C.F.M.; HACKER, R.R. Novel methodology allows simultaneous measurement of true phosphorus digestibility and gastrointestinal endogenous phosphorus outputs in studies with pigs. Journal of Nutrition, v.131, p.2388-2396, 2001.

HANSON, A.R.; XU, G.; LI, M.; WHITNEY, M.H.; SHURSON, G.C. Impact of dried distillers grains with solubles (DDGS) and diet formulation method on dry matter, calcium, and phosphorus retention and excretion in nursery pigs. Animal Feed Science and Technology, v.172, p.187-193, 2012.

JONGBLOED, A.W.; KEMME, P.A. Apparent digestible phosphorus in the feeding of pigs in relation to availability, requirement and environment. Digestible phosphorus in feedstuffs from plant and animal origin. Netherlands Journal of Agricultural Science, v.38, p.567-75, 1990.
JONGBLOED, A.W.; MROZ, Z.; KEMME, P.A. The effect of suplementary Aspergilus niger phytase in diets for pigs on concentration and apparent digestibility of dry matter, total phosphorus, and phytic acid in different sections of the alimentary tract. Journal of Animal Science, v.70, p.1159-1168, 1992.

KAVANAGH, S.; LYNCH, P.B; MARA, O.F.; CAFREY, P.J.A. Comparison of total collection and marker technique for the measurement of apparent digestibility of diets for growing pigs. Animal Feed Science and Technology, v.89, p.49-58, 2001.

KEMME, P.A.; JONGBLOED, A.W.; PEET, G.F.V. Em: Stikstof en fosfor in de voeding van eenmagige landbouwhuisdieren in relatie tot de milieu-problematiek. Kwaliteitsreeks nr. 25. Productschap voor Veevoeder. Den Haag, Nederland, 1993.

KIM, B.G.; LEE, J.W.E.; STEIN, H.H. Energy concentration and phosphorus digestibility in whey powder, whey permeate, and low-ash whey permeate fed to weanling pigs. Journal of Animal Science, v.90, p.289-295, 2012.

LINDEMANN, M.D.; QUANT, A.D.; MONEGUE, J.S.; WANG, M.; CROMWELL, G.L.; NEWMAN, M.C. Evaluation of antibiotic effects on phosphorus digestibility and utilization by growing-finishing pigs fed a phosphorusdeficient, corn-soybean meal diet. Journal of Animal Science, v.88, p.1752-1758, 2010.

NÄÄS, I.A. Técnicas modernas para melhorar a produtividade dos suínos através do controle ambiental. In: SEMINÁRIO INTERNACIONAL DE SUINOCULTURA, 2., 1997, Campinas, SP. Anais... Campinas: Universidade de Campinas, 1997. p.19-26. 
Rev. Bras. Saúde Prod. Anim., Salvador, v.16, n.3, p.544-557 jul./set.., 2015 http://www.rbspa.ufba.br ISSN 15199940

PEKAS, J.C. Versatile swine laboratory apparatus for physiologic and metabolic studies. Journal of Animal Science, v.27, p.1303-1306, 1968.

PETERSEN, G.I.; PEDERSEN, C.; LINDEMANN, M.D.; STEIN, H.H. Relative bioavailability of phosphorus in inorganic phosphorus sources fed to growing pigs. Journal of Animal Science, v.89, p.460-466, 2011.

PETERSEN, G.I.; STEIN, H.H. Novel procedure for estimating endogenous losses and measurement of apparent and true digestibility of phosphorus by growing pigs. Journal of Animal Science, v.84, p.2126-2132, 2006.

PETTEY, L. A.; CROMWELL, G.L.; LINDEMANN, M.D. Estimation of endogenous phosphorus loss in growing and finishing pigs fed semipurified diets. Journal of Animal Science, v.84, p.618-626, 2006.

POTTER, L.M. Bioavailability of phosphorus from various phosphates based on body weights and toe ash measurements. Poultry Science, v.67, p.96-102, 1988.

RICHERT. Macro minerals for swine diets. National Swine Nutrition Guide. 2010. Avialable in:

$<$ http://www.usporkcenter.org/FileLibra ry/External/USPCE/NSNG/NSNG-

Macro-

minerals\%20for\%20Swine\%20Diets(1). pdf $>$.

ROJAS, O.J.; STEIN, H.H.

Digestibility of Phosphorus by Growing Pigs of Fermented and Conventional Soybean Meal without and With Microbial Phytase. Journal of Animal Science, v.90, p.1506-1512, 2012.
ROSTAGNO, H.S.; ALBINO, L.F.T.;

DONZELE, J.L.; GOMES, P.C.; OLIVEIRA, R.F.M.; LOPES, D.C.; SOARES, A.F.; BARRETO, S.L.T. Tabelas brasileiras para aves $\mathrm{e}$ suínos. Viçosa, MG: Universidade Federal de Viçosa, 2011. 252p.

ROSTAGNO, H.S.; FEATHERSTON, W.R. Estudos de Métodos para a Determinação da Disponibilidade de aminoácidos em pintos. Revista Brasileira de Zootecnia, v.6, p.64-76, 1997.

SARAIVA, A.; DONZELE, J.L.; OLIVEIRA, R.F.M.; ABREU, M.L.T.; SILVA, F.C.O.; GUIMARÃES, E.F.; KIM, S.W. Phosphorus requirements for 60 - to $100-\mathrm{kg}$ pigs selected for high lean deposition under different thermal environments. Journal of Animal Science, v.90, p.1499-1505, 2012.

SELLE, P.H.; RAVINDRAN, V. Phytate-degrading enzymes in pig nutrition. Livestock Science, v.113, p.99-122, 2008.

SHURSON, J.; POMERENKE, J. Use of US DDGS in practical swine diet formulations. University of Minnesota. International Distillers Grains Conference. 2008. Disponível em: $<$ http://www.thepigsite.com/articles/262 9/use-of-us-ddgs-in-practical-swinediet-formulations $>$. Acessado em: 12 ago. 2013.

STEIN, H.H.; KADZERE, C.T.; KIM, S.W.; MILLER, P.S. Influence of dietary phosphorus concentration on the digestibility of phosphorus in monocalcium phosphate by growing pigs. Journal of Animal Science, v.86, p.1861-1867, 2008. 
Rev. Bras. Saúde Prod. Anim., Salvador, v.16, n.3, p.544-557 jul./set.., 2015 http://www.rbspa.ufba.br ISSN 15199940

TEIXEIRA, A.O.; LOPES, D.C.; GOMES, P.C.; LOPES, J.B.; COSTA, L.F.; FERREIRA, V.P.A.; PENA, S.M.; MOREIRA, J.A. Níveis de substituição do fosfato bicálcico pelo monobicálcico em dietas para suínos nas fases de crescimento e terminação. Revista Brasileira de Zootecnia, v.34, p.142150, 2005.

TEIXEIRA, A.O.; LOPES, D.C.; LOPES, J.B.; VITTI, M.S.S.; GOMES, P.C.; ROSTAGNO, H.S.; MOREIRA, J.A.; INÁCIO, F. Determinação da biodisponibilidade do fósforo de diferentes fontes por intermédio da técnica de diluição isotópica, com suínos em crescimento. Revista Brasileira de Zootecnia, v.33, p.12311237, 2004.

UNIVERSIDADE FEDERAL DE VIÇOSA - UFV. Sistema para Análises Estatísticas e Genética SAEG. Versão 8.0. Viçosa, MG:

Universidade Federal de Viçosa, 2000.

Data de recebimento: $16 / 04 / 2014$

Data de aprovação: 27/08/2015 